\title{
TWO UNPUBLISHED LETTERS: WALT WHITMAN TO WILLIAM JAMES LINTON, MARCH 14 AND APRIL 11, 1872
}

\author{
Ted Genoways
}

The Two FOLLOwING unpublished letters by Walt Whitman to William James Linton, the preeminent British wood-engraver and a poet of modest reputation, were recently discovered among items available for purchase at two separate manuscript dealers. ${ }^{1}$ Though Whitman did not include the year in the dateline of either letter, all internal and external evidence confirms that both letters were written during Whitman's brief visit to Brooklyn in the spring of 1872, at which time he arranged to have Linton prepare an engraving he intended to use as the frontispiece of the 1876 edition of Leaves of Grass.

TO WILLIAM J. LINTON

Brooklyn, New York / March 14

My dear Mr. Linton,

I think of wanting this engraved (exactly this size, and general design) for a frontispiece for my next edition of "Leaves of Grass." Do you think it would make a good picture?-Would it suit you to do it for me? If yes what would be the price? I shall be here for some two weeks yet-then to return to Washington-

- Send me word by mail, \& if convenient appoint an hour, day, \& place in New York, where we could meet $\&$ talk it over-Bring this picture with you. I will be there as you appoint.

Walt Whitman

TO WILLIAM J. LINTON

4.11.[1872]

Brooklyn, Thursday forenoon / April 11

My dear Linton,

I have just been spending an hour looking over "The Future"-and the "Ireland" you sent me- $\&$ stopping at certain pieces here $\&$ there, $\&$ reading them quite carefully, \& dwelling upon them. They touch me deeply-indeed more than anything of the kind had previously done - the undertone of anguish and despair-the Laocoon struggles, (apparently useless) under the tightening grip[p]ing folds of the serpent- the cries \& complaints \& remonstrances \& calls for help - somehow, in your verses, brought the fearful condition of the laboring millions not only of Ireland, Italy, Poland \&c- but all Europe-more vividly than ever yet, before me.

And it is well for me to get such reminding's- 
But my own vein is full of hope, promise, faith, certainty-I see how an American-I for instance-cannot perhaps realize the peoples desperate condition over the major part of the world-

- This point you have to-day brought up sharply before me.

I return to Washington Saturday.

Walt Whitman

The first of these two new letters is dated March 14 (see facsimile on back cover). In the credit line for the engraving in the 1876 Leaves of Grass (see Figure 1), Whitman identified the portrait as "Photograph'd from life, Washington, 1871, by G.C. Potter, and drawn on wood by W.J. Linton." 2 The March 14 letter opens by referring to an enclosed photograph, now lost: "I think of wanting this for a frontispiece for my next edition of 'Leaves of Grass.' Do you think it would make a good picture?"3 The enclosure of this photograph and the nature of the remainder of the letter indicate that this is the first communication concerning the engraving. Considering that the Potter photograph was taken in 1871 and that Whitman wrote to Linton on March 22, 1872, the letter would have to have been composed in 1871 or 1872 . Because the letter was written from Brooklyn-and Whitman was in Washington in the spring of 1871 - the letter can only have been composed in 1872 .

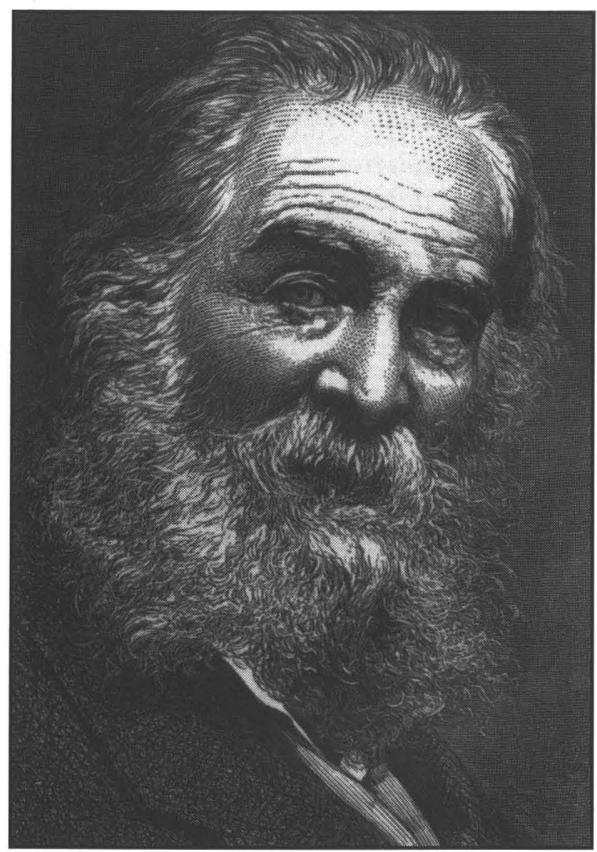

Figure 1. W. J. Linton's engraving of Whitman, 1876.
There is no record of why Whitman chose Linton specifically for the engraving; however, it seems likely that the suggestion came from Anne Gilchrist. Linton had supplied the dazzling wood-engravings to her husband Alexander Gilchrist's Life of William Blake, published in England in 1863, and had remained close friends with the Gilchrists, even after his departure from England to New Haven, Connecticut, in 1866.4 On February 8, 1872, Whitman wrote Anne Gilchrist: "I am going on to New York soon to remain there a few weeks." ${ }^{5} \mathrm{On}$ March 15, now in New York, Whitman noted in a letter to John Burroughs: "Rec'd a letter from Mrs. Gilchrist in England" (Corr. $2: 168)$. Unfortunately her original is lost; however, given that her 
letter arrived on or around March 14, it seems likely that Anne Gilchrist suggested that Whitman call on Linton. On that very date he wrote to Linton, not only to inquire about the engraving, but also suggested that Linton "appoint an hour, day, \& place in New York, where we could meet \& talk it over."

Linton's response is also missing, but apparently he asked for a large sum of money to do the engraving, because on March 22, 1872, Whitman replied:

I have been delaying to write you about the portrait in answer-wanting you to do it\& wanting, if I could arrange it, to give you the full price-I will not have the job done by any second-rater, $\&$ have concluded to give it up for the present-unless it could be done by you for $\$ 50$. $^{6}$

Linton agreed to the price. Years later Whitman told Horace Traubel that in reply Linton "wrote me that if he had been rich he would have made it for nothing but as he was not he would charge me fifty dollars for it." Perhaps it was in that same letter that Linton took advantage of this favor by sending Whitman two of his own poems for evaluation.

The second unpublished letter presented here is Whitman's response. Though dated "April 11" with no year, this letter also can be definitively placed in 1872 . Most obviously, the letter's postscript states "I return to Washington Saturday." This is consistent with Whitman's statements in the March 14 letter ("I shall be here for some two weeks yet-then to return to Washington-") and March 22 letter ("I return to Washington in ten or twelve days"). ${ }^{8}$ Furthermore, "April 11 " is emended "Thursday forenoon." April 11 would have fallen on a Thursday in 1867, 1872, 1877, and so on. Since Whitman did not make Linton's acquaintance until 1872, any earlier date can be discounted. Any date later than 1875 can likewise be discounted, because Whitman suffered a stroke in 1873 and moved to Camden, New Jersey, on May 20 of that year. His last visit to Washington came in November 1875. Therefore, the date "Thursday forenoon, / April 11" can only apply to that same spring in 1872 .

Linton was by no means a significant poet, but his skills as an engraver and editor allowed him intimate contact with an array of notable British or American writers of the nineteenth-century-Carlyle, Thackeray, Bryant, Lowell, Tennyson, Whittier, Emerson, and Longfellow, to name a few. Whitman's kind response was no doubt born of a mixture of indebtedness and guile; however, in so doing he also gently registers his aversion to Linton's "undertone of anguish and despair," saying "my own vein is full of hope, promise, faith, certainty." This chiding may have colored Linton's own late opinion of Whitman's poetry: he wrote in his Three Score and Ten Years, published in 1894, that Whitman was "a true poet who could not write poetry, much of 
wilfulness accounting for his neglect of form, perhaps as fatal a mistake in a poet as in a painter" (217).

Whether due to Linton's wounded ego or simply the difficulty of travelling to New York, the two men did not meet before Whitman's departure. If Whitman attempted to contact Linton during his subsequent visit to New York and New England in June and July 1872, no record has been recovered. By October 4, 1872, Whitman was concerned enough about Linton's silence to write him, "How do you get on with the picture?. . I have not heard from you for some months" (Corr., $2: 186)$. In late 1872 or early 1873 , the two did eventually meet, Linton recalling, "Walt Whitman I first saw at his desk in the Treasury at Washington" (Three Score, 216-217). They met again, after Whitman's stroke, in Camden in early November of 1873 . Whitman wrote Peter Doyle that "Mr. Linton, the artist, has lately called upon me" (Corr., 2:256). Linton confirmed that "I called on him at his home (his brother's house) in Camden, over the river from Philadelphia" (Three Score, 217).

When the engraving appeared in Leaves of Grass in 1876, it was positioned not as a frontispiece but opposite "The Wound-Dresser." This repositioning does not appear to have been a cooling of Whitman's pride in the engraving; in fact, the poem "Out from Behind this Mask" was directly inspired by the rendering and originally carried the subtitle, “To confront My Portrait, illustrating 'the Wound-Dresser,' in LEAVES OF GRASS." 10 With Whitman's permission, Linton subsequently used the portrait as the frontispiece to his Poetry of America (London, 1878).

Though their contact grew more sporadic, the two men continued to correspond nearly until Whitman's death. Linton remembered, "I had some friendly correspondence and interchange of writing with him. I liked the man much, a fine-natured, good-hearted, big fellow" (Three Score, 217). Many of those later letters are well-documented in Horace Traubel's With Walt Whitman in Camden and Edwin Haviland Miller's edition of The Correspondence. These two newly discovered letters add to and help complete the correspondence by revealing important details of the early correspondence between Whitman and Linton.

\section{Minnesota Historical Society Press}

\section{NOTES}

1 The March 14 letter was located at Heritage Book Shop, Inc., in Los Angeles, and is published by permission of Susanne Bordner; the April 11 letter was located at Bromer Booksellers, Inc., in Boston, and is published by permission of David J. Bromer. Additional thanks are due to Anne Dane at Bromer Booksellers, Inc., for her assistance in providing photocopies of the April 11 letter. The letters are now in the Kendall Reed Collection.

2 Leaves of Grass, 1876, vi. 
3 One of the original prints of this portrait now resides in the Bayley Collection at Ohio Wesleyan University. For the photograph and Linton's engraving, see Ed Folsom, "The Photographs of Walt Whitman" Walt Whitman Quarterly Review 4 (Fall/Winter 1986-1987), 7-42.

4 For Linton's account of preparing the Blake engravings, see his Three Score and Ten Years, 181-182. For evidence of Anne Gilchrist's personal acquaintance with Linton, see her letter to him, inviting him to the Gilchrist home and praising the Whitman portrait, dated December 11, 1877, held in the John Hay Library at Brown University. Subsequent citations to Linton's book will appear parenthetically as Three Score.

5 Walt Whitman, Correspondence, ed. Edwin Haviland Miller (New York: New York University Press, 1961), 2:164. Abbreviated parenthetically as Corr.

6 Corr., 2:171-172.

7 Horace Traubel, With Walt Whitman in Camden (New York: 1915), 2:429.

8 Corr., 2:172.

9 Leaves of Grass, 1876, facing p. 285.

10 Two Rivulets, 24. For an excellent discussion of the interplay between the engraving and the poem, see Harold W. Blodgett's "Whitman and the Linton Portrait," Walt Whitman Newsletter 4 (September 1958), 90-92. 